\title{
Philip Furia and Laurie Patterson. The Songs of Hollywood
}

Reprint Edition. Oxford and New York: Oxford University Press, 2012. [x, 280 p. ISBN: 978-0199931750. \$31.50 (hardcover)] Illustrations, filmography, index, and song index.

\author{
JENNIFER L. ROTH-BURNETTE \\ UA Early College, University of Alabama \\ jroth-burnette@ccs.ua.edu
}

$\mathrm{W}$ ith nearly 200 film stills and several music analyses accessible to the general reader, authors Philip Furia and Laurie Patterson (both of the University of North Carolina Wilmington), offer a vivid survey of musical Hollywood films and their songs, beginning with the first forays into melding sound to film in the late 1920s, and extending nearly to the present day. While quite engaging and accessible to general audiences, the depth of the historical and biographical data on persons and institutions involved in the emergence of song in film make this a worthwhile read for the Hollywood song aficionado. In addition, though a scholarly musical background is unnecessary, film music scholars and various music specialists may find the book enjoyable and its information valuable to their own research. Furia and Patterson present a masterfully researched history populated by a large and colorful cast of songwriters, lyricists, directors, producers, and performers, situated within the environments of their employers, production studios, economic conditions, and the synergistic mix of personalities that have shaped a widely diverse set of approaches to music, and particularly song, in Hollywood films. From the outset, they situate Hollywood song within the broader field of American popular music in terms both of idiom and economic product, while distinguishing it from the song of the Broadway musical, and they proceed to develop a compelling case that Hollywood film and its associated songs shaped one another so particularly as to deserve treatment on their own terms.
Much of the book is biographical, setting forth both the lives of individuals who shaped song in film through their creative work and performance, and the network of interrelationships, professional partnerships, and friendships through which they influenced one another. Furia and Patterson succeed, by offering stories and anecdotes that lend perspective on individual personalities, interests, and motivations, in relating an engaging and highly informative story of the individuals and institutions responsible for the development and deployment of song in Hollywood films. The authors draw on biographies of songwriters and producers, memoirs, and histories of production companies, publishers, and the like, for the historical and biographical data they present, as well as for the many personal quotes they offer in their portrayals of individuals. For the song and film analyses, they rely almost exclusively on primary sources-the films themselves. Furia and Patterson masterfully weave together a very detailed and nuanced historical backdrop from secondary sources, and in their analysis of primary source material (whereas many general-readership books seem to avoid primary source material). A study intended for music scholars would be expected to include more primary-source work for the biographical material, and much more in-depth musical analysis (e.g., examining autograph scores or offering various hearings of songs in respect to voice leading, harmonic progression, or instrumentation); however, this book aims for a broader audience than music scholars alone. 
Each chapter title evokes a particular song or film scene. These titles provide the reader, whether previously schooled in Hollywood song or learning for the first time, mental indices for chapter topics and the important musical and cinematic developments belonging to each. Chapter 1, "You Ain't Seen Nothin' Yet," describes the Warner Bros.' Vitaphone program, one of the early technologies that allowed the integration of sound and film. This integration catapulted Al Jolson to stardom in The Jazz Singer (1927) and subsequent films. These transformative events are set within a broader context marked by a shift in the previous hegemony of stage over screen performance, and the migration of Tin Pan Alley songwriters and Broadway musicians to the studios of Hollywood.

Chapters 2 through 5 each present an intriguing and richly peopled history of the early years of musical film at MGM, Paramount, Warner Bros., and RKO, describing the distinctive creative forces that shaped the character and output of each studio. These efforts range from the keen artistic direction of Irving Thalberg, integrating song and film at MGM, to the adaptations of operetta by Ernst Lubitsch and Rouben Mamoulian at Paramount, the various incarnations of the "backstager" formula at Warner Bros., and the creation of the Fred Astaire-Ginger Rogers performance team at RKO. MGM was the first in its cohort to secure the majority share of a Tin Pan Alley music publishing firm and its large song repertory, and the other studios quickly followed suit. Furia and Patterson explore, throughout the book, how this acquisition would guarantee each group a distinctive set of already-popular songs, often the entire output of an individual songwriter (a Cole Porter or a George Gershwin, for instance), and how it would shape their production choices through the ensuing decades. These Hollywood studios are also considered in light of the Great Depression, whose exigencies affected each studio differently, and resulted in choices that would shape the studios' interests going forward.

In these chapters, the authors also address the significant technological leaps that would foster a more fluid integration of music and film, and the emergence of an aesthetic that valued "integral" songs - those that advanced the dramatic narrative and expressed the inmost thoughts and feelings of the characters-over strictly "performance" numbers. This aesthetic, explored in different ways by individual directors and songwriters, went hand in hand with the discovery of film's potential for casual, intimate performance-in strong contrast to the formal style and operatic voice production of the stage. The tension (whether playful or serious) between the formal and the informal appears under guises that touch both music and film, contrasting classical and popular music, "highbrow" and vernacular language, "staged" and intimate situations. Early in the book, the authors point out that the first "talkies" quickly assimilated an American vernacular informed by Broadway, and they then proceed to establish, in numerous examples throughout the book, that the casual and intimate perspective fostered by a camera-in contrast to the formal distance of a live stage performance-made room both for informal language and music and ushered in a new aesthetic for musical film. One such example is "Thanks for the Memory," from director Mitchel Leisen's The Big Broadcast of 1938 (released in the same year), in which a divorced couple, portrayed by Bob Hope and Shirley Ross, reminisce about their marriage. The analysis presented by Furia and Patterson focuses on contrasting elements in text and delivery, beginning with images in the song text that contrast the highly romantic and the extremely domestic, and use of language that highlights the characters' tension between their need to be sophisticated and somewhat removed, and their temptation to be sentimental. As the song progresses, their façades crumble and their emotional pain is revealed. The casual intimacy of this scene, in which the characters are filmed close-up to reveal their facial expressions and subtle body language, as well as the half-sung, half-spoken delivery, offer a dramatic effect not possible from the distance of a stage. In another example, Furia and Patterson show how the "opera versus pop" conflict itself serves as the basis of the plot of director W. S. Van Dyke's San Francisco (1936), in which an out-of-work opera singer played by Jeanette MacDonald must "jazz up" her style to appear in a nightclub act. The entire film is concerned with a set of tensions between "highbrow" and popular, formal and casual, staged and intimate.

Having set the background for the emergence of each studio into musical film in the first half of the book, Furia and Patterson begin in Chapter 6 to outline a chronological arc, beginning with the prolific production of the 1930s, and moving in Chapter 7 to a consideration of the creative work of Arthur Freed at MGM, and the discovery of Judy Garland. The emphasis on MGM as a locus of particular ingenuity persists through Chapters 8 and 9, on the 1940s and 1950s. Chapter 10 remains oriented to the 1950s, drawing the oeuvre of the other major studios more robustly into the discussion, and giving fuller voice to the authors' 
interest in "integrated" song. The concluding Chapter 11 treats the demise of a "golden age" of integrated song in the 1960s and beyond, touching on particular films of the 1970s, 1980s, and 2000s with a hopeful note that films will continue to incorporate song in "dramatic and moving fashion," and a reassertion that the "Songs of Hollywood" are the songs of a bygone era that continues, referentially, to inform the present.

Throughout The Songs of Hollywood, Furia and Patterson focus on the dramatic role of song in Hollywood film, and are particularly concerned with the expressive potential of music to be an integrated feature of a dramatic narrative, in which conventional characters can burst spontaneously into song that advances the narrative, further develops character, or expresses key thoughts and feelings. Films built around integrated song are identified in contrast to others, built around performance-for instance, those in which the primary roles are those of musicians and stage performers, thus providing their characters with a realistically plausible reason to sing and dance. Though some of the latter examples, such as director Harry Beaumont's The Broadway Melody (1929), Mervyn LeRoy's Gold Diggers of 1933 (1933), and Henry King's Alexander's Ragtime Band (1938) are loosely integrated, in which certain song performances resonate with the singer's dramatic situation, they more often advance songs simply as entertaining performance numbers, without any more profound connection to the dramatic arc of the film.

In the process of their discussion, the authors cover a panoply of song examples that reveal the enormous variety in relationships between song, dramatic narrative, and character development. During the course of the book, it becomes clear that some of the most ingenious musical films include what the authors term "integrated" song-a song that is not placed simply for entertainment value, but because it is used to develop character, it is used to express emotions central to the dramatic situation or to advance the plot. For instance, Furia and Patterson focus on the "integral" qualities of director Stanley Donen's Seven Brides for Seven Brothers (1954), in which the songs written by Johnny Mercer and Gene De Paul, specifically for this film, establish character and geography (through the texts' colorful imagery and use of dialect) and advance the storyline. By contrast, films like Vincente Minnelli's An American in Paris (1951) were song anthologies around which a plot was woven for the purpose of presenting the songs in film. The quality of "integration" (or lack thereof) is clearly part of the value system by which the authors judge the films they treat. Throughout their presentation, the authors' focus is to present the song itself; rarely do they deal with orchestral music, which would have added some valuable discussion to their book. Take, for example, Singin' in the Rain (the film featured on the cover of the book), in which several of the songs return or foreshadow their appearances in the film as orchestral tunes and as part of a medley. Some of them appear in a minor key to highlight the unfolding drama's tone while others work like connective tissue (transition material).

Furia and Patterson also mention, without probing in depth, the social attitudes of the early twentieth century that rendered it more plausible in film for blacks, children, or cartoons to burst spontaneously into song, than for conventional, adult, white characters. Although one can appreciate the authors' undivided focus on Hollywood song and its shaping economies, individuals, technologies, and institutions, it seems that some further consideration of implicit social inequities and characterizations could lend greater depth to the broader discussion of song in film, along the lines they have established.

In every chapter, the authors deliver not only a broad and mesmerizing history, but very worthwhile analyses of selected songs and scenes that also lead to an understanding of their dramatic function. These analyses are key to the argument in favor of integrated song, and through these analyses the authors promote this argument in a way that remains accessible to non-musicians, while treating in worthwhile depth the dramatic role of a song within its larger scene or narrative. Furia and Patterson weave together a set of incisive observations on dramatic impulse, musical style and texture, accent and key change, vocal delivery, and expression. This effort presents nuanced and important interpretations of the ways in which song and film mutually reinforce the expressive goals of a given narrative. Readers of this history will most likely wish to revisit the films treated, to digest fully the detailed analyses provided by the authors and perhaps to carry their perspectives and methods into other corners of the repertory.

Jennifer L. Roth-Burnette is the Associate Director of UA Early College, an academic program of The University of Alabama, where she also teaches courses in music and political movements, world music, and music of the Middle Ages. She earned the $\mathrm{PhD}$ in musicology from New York University and continues to pursue active research interests in Parisian organum and the medieval art of memory. 